\title{
Acute respiratory distress syndrome after traumatic brain injury in Purwokerto-Indonesia
}

\author{
Munjiati ${ }^{1}$, Walin $^{2}$, Herry 3 , Ferry ${ }^{4}$ \\ 1,2,3 Diploma In Nursing, Polytechnic of Health Purwokerto-Semarang, Indonesia. Email: munjiatiifa@yahoo.co.id \\ ${ }^{4}$ Margono Soekarjo Hospital, Purwokerto, Indonesia
}

\begin{abstract}
Background: Traumatic brain injury was most source morbidity and mortality at patient by real trauma. Traumatic brain injury case who dead before to the hospital was caused by shock, hypoxemia and hypercapnia. So needed basic of knowledge and ability to take care of patient of breath disease.

Purpose: To explore the factors that influence respiratory distress on traumatic brain injury at Prof. Dr. Margono Soekarjo hospital in Purwokerto, Indonesia

Methods: The kind of this research was correlation with using cross sectional approach. The population of this research was all patients with traumatic brain injury in the emergency ward Prof. Dr. Margono Soekarjo hospital Purwokerto on November-Desember 2017. The sample take as 19 person. The analyzed used was Coefficient Contingency Test.

Results: The result of this research shows that patient with traumatic brain injury had respiratory distress $(57.9 \%)$ higher following by phlegm's accumulation (52,6\%) also had the decrease of consciousness $(47,4 \%)$. There was real influence as statistic between phlegm's accumulation and respiratory distress on traumatic brain injury $(p=0.040)$. There was as statistically significant between the decrease of consciousness and respiratory distress on traumatic brain injury $(p=0,009)$.

Conclusion: It can be concluded that there was a statistically significant influence between decreased awareness of respiratory distress on traumatic brain injury $(p=0.0009)$

\section{Keywords : Acute respiratory distress syndrome; Traumatic brain injury; Consciousness}

\section{INTRODUCTION}

Traumatic brain injury Is a global health problem as a cause of death, deficit mental and disability (Gustia \& Marunung, 2018). Traumatic traumatic brain injury is a major source of morbidity and mortality in patients with real trauma. Of the $20 \%$ of traumatic brain injury cases that die before entering the hospital the most common causes are shock, hypoxemia and hypercapnia. So we need a basic knowledge and ability in the management of respiratory disorders patients. From the data in the medical records of Margono Regional Hospital in the last six months from January to June 2017, 632 cases of traumatic brain injury with respiratory distress were found, consisting of mild, moderate and traumatic brain injury . Obtained minor traumatic

injury 98 cases and on traumatic brain injury 117 , in on traumatic brain injury tend to have respiratory distress (Huda, 2018).

Based on the description above, writing is expected to find out more about respiratory distress in on traumatic brain traumatic brain injury injuries, so that it is expected to reduce mortality and morbidity, as well as to realize quality services and more professional nursing services. Based on these problems, a research question can be formulated ". What factors affect respiratory distress in traumatic brain injury ? This study aims to determine the factors that influence the distress of breathing in injuries heading Prof. Dr. Margono Soekarjo Purwokerto. Knowing the factors that affect the respiratory distress in traumatic brain injury is
\end{abstract} brain injury 417 cases, moderate traumatic brain 
expected to improve the handling of these patients so that it will reduce mortality (Hutagalung, 2019).

Traumatic brain injury by Glasgow coma scale (GCS), a system standardized assessment used to assess the level of awareness in patients with impaired consciousness. GCS is a numerical calculation of cognitive, behavioral, and neurological functions. Traumatic brain injury are generally interpreted as injuries that can result in scalp or the scalp, skull bones, and bones that make up the face or brain (Ban, Son, Yang, ChungLee, \& Han, 2010).

Traumatic brain injury caused by a "Sudden force" on the head due to accidents, sports accidents, persecution. Three mechanisms that contribute to head trauma are acceleration, deceleration and deformation.

Increased Pressure intracranial is a complex manifestation caused by various neurological conditions. It occurs suddenly and requires surgical intervention. The contents of the skull or cranium are brain tissue and LCS (Liquor Cerebrospinalis). Thespace is intracranial filled by $80 \%$ of the brain, $10 \%$ of blood and $10 \%$ of brain fluid. Increasing the volume of one of the contents of the brain increases pressure intracranial, because the cranial space is hard, closed, and cannot expand. An increase in one of the contents of the brain is usually accompanied by an opposite change from another volume. The brain tissue cannot enlarge without accompanied by the flow of cerebrospinal fluid and the circulation of the brain. Pressure continues to increase so that blood flow in the brain decreases and there is an perfusion inadequate. Because perfusion is inadequate causing an acute circle causing an increase in $\mathrm{PCO} 2$ and a decrease in $\mathrm{PO}_{2}$. These changes affect the vasodilatation and edema brain. Brain edema will increase intracranial pressure and pressure on tissue nerve (Menk, Scharping, Moreci, Zeng, Guy, Salvatore, \& Delgoffe, 2018).

A respiratory distress can be defined as an acute, life-threatening condition due to inadequate O2 uptake and $\mathrm{CO} 2$ release (Aveyard, Cooper, Fletcher, \& Rutherford, 1993). Physiologically, shortness of breath occurs due to the supply of $\mathrm{O}_{2}$ in the tissue is not proportional to the $\mathrm{O}_{2}$ needed. This happens because of lack of $\mathrm{O} 2$, excess $\mathrm{CO} 2$, hyperactivity, emotions, acidosis. The brain can function properly if oxygen and glucose requirements can be met. The brain without oxygen reserves, so a lack of blood flow to the brain even though it will briefly cause dysfunction. Similarly, the need for glucose as a fuel for brain metabolism should not be less than $20 \%$, because it will cause coma. Glucose needs as much as $25 \%$ of all the body's glucose needs, so if plasma glucose levels drop to $70 \%$ there will be symptoms of early dysfunction cerebral. When the brain experiences hypoxia, the body tries to meet oxygen demand through metabolic processes anaerobic, which can cause blood vessel dilation.

Management of traumatic brain injury according to namely by maintaining the function of $A B C$ ( Airway, Breathing, Circulation), assessing neurological status, decreasing the risk of ischemia cerebral, monitoring intracranial pressure )where the two main problems in on traumatic brain injury are hypoxia and hypovolemia (Shock) (Putrapratama, Wiraagni, \& Artanti, 2017). Patients who are unconscious and in the supine position may experience airway obstruction. The tongue most often causes airway obstruction. As soon as the airway obstruction is handled attention is aimed at bleeding and managing it. Decreased blood pressure will cause a noticeable decrease in oxygen delivery in the brain. Because CPP $=$ MAP - ICP $(\mathrm{CPP}=$ cerebral perfusion pressure, $\mathrm{MAP}=$ mean arterial pressure, $\mathrm{ICP}=$ intracranial pressure). In on traumatic brain injury an increase in ICP. When blood pressure drops, CPP will drop. A decrease in blood pressure due to hypovolemia will cause CPP to decrease greatly. convulsion This Can occur after a minor traumatic brain injury, which is very meaningful for doctors who handle emergencies.

Diagnostic tests should be as soon as possible and as often as possible a complete examination includes evaluation of the degree of patient awareness, do not use terms like coma, semi coma but it is better to use GCS. Blood tests: $\mathrm{Hb}$, hematocrit may need blood gas analysis, CT scan and IMR (Zhu, Wang, \& Craig, 2019).

Factors affecting respiratory distress include a decrease in consciousness due to cerebral trauma usually leading to respiratory failure. Several locations in the cerebral hemisphere regulate voluntary control of the muscles used in breathing, in

Munjiati', Walin², Herry ${ }^{3}$ Diploma In Nursing, Polytechnic of Health Purwokerto-Semarang, Indonesia. Email: munjiatiifa@yahoo.co.id

Ferry ${ }^{4}$ Margono Soekarjo Hospital, Purwokerto, Indonesia 
synchronization and coordination of the cerebellum in respiratory muscles. Cerebellum also has some control over frequency control and breathing rhythm. Normal mucus / mucus forms about mucus $100 \mathrm{ml}$ of in the respiratory tract every day this mucus is produced by the tracheobronchial gland in the branching blood bronchial. Loss of reflex to swallow that a risk of respiratory lung reflex swallowing involves components of sensory and motor nerves IX (nerve glossopharyngeal and nerve $\mathrm{X}$ (vagus). Impaired nerve may cause nerve and muscles to swallow.

\section{RESEARCH METHODS}

Study was correlational and approach. cross sectional In at the same time the researcher measured the results and exposure to study participants. The design of this study was used to find out more about the factors that affect the respiratory distress in head injuries. This study was conducted at Prof. Dr. Margono Soekarjo Hospital with consideration of the high number of traumatic brain injury sufferers in 6 last month (January - June 2017) This study was conducted for 3 months (1 November - 31 December 2017. This study used a purposive sampling technique. Criteria for inclusion of traumatic brain injury with GCS 3-8 and traumatic brain injury patients with family permission who were willing to be the number of respondents in use in this study as many as 19 patients. The research instrument used by using the Check list sheet to record the condition, clinical signs of respiratory distress by observation and documentation of the patient's Medical Record to see the patient's identity, results of supporting examinations and diagnoses medical. This research, carried out by researchers and assisted by 2 nurses as observers of data obtained after processing was analyzed by univariate analysis. To describe each variable by describing the percentage, number of events and frequency for each variable studied and Bivariate analysis with the Coefficient Contingency test.

\section{RESEARCH RESULTS}

Table 1. Characteristics of Respondents by Age and Gender $\mathrm{N}=19$

\begin{tabular}{lcc}
\hline Characteristics of Respondents & Frequency (f) & Percentage (\%) \\
\hline Age (Years) & & \\
$16-22$ & 6 & 31,58 \\
$23-29$ & 7 & 36,84 \\
$30-36$ & 4 & 21,05 \\
$37-42$ & 2 & 10,53 \\
Gender & & \\
Male & 12 & 63,16 \\
Female & 7 & 36,84 \\
\hline
\end{tabular}

Based on the data in Table 1 it can be seen that the highest number those aged between 23-29 years 7 aged $(36.84 \%)$, and male $12(63,16 \%)$

Munjiati', Walin ${ }^{2}$, Herry ${ }^{3}$ Diploma In Nursing, Polytechnic of Health Purwokerto-Semarang, Indonesia. Email: munjiatiifa@yahoo.co.id

Ferry ${ }^{4}$ Margono Soekarjo Hospital, Purwokerto, Indonesia 
Malahayati International Journal of Nursing and Health Science, Volume 02, No.2, September 2019: 66-72

Acute respiratory distress syndrome after traumatic brain injury in Purwokerto-Indonesia

Table 2. Occurrence of Accumulation Mucus

\begin{tabular}{lcc}
\hline \multicolumn{1}{c}{ Accumulation Mucus } & Frequency (f) & Percentage (\%) \\
& & \\
\hline Occurrence & 10 & 52,6 \\
Unoccurrence & 9 & 47,4 \\
\hline
\end{tabular}

Table 3. Decreased Level of Consciousness

\begin{tabular}{lcc} 
& & $\mathrm{N}=19$ \\
\hline \multicolumn{1}{c}{ Category } & Frequency (f) & Percentage (\%) \\
\hline Mild & & \\
Severe & 10 & 47,4 \\
\hline
\end{tabular}

Table 4. Occurrence of Acute Respiratory Distress Syndrome

\begin{tabular}{lcc} 
& & $\mathbf{N}=19$ \\
\hline Acute respiratory distress syndrome & Frequency (f) & Percentage (\%) \\
\hline Occurrence & & \\
Unoccurrence & 11 & 57,9 \\
\hline
\end{tabular}

Table 5. The Accumulation Mucus and Acute respiratory distress syndrome

\begin{tabular}{lccccccc}
\hline $\begin{array}{c}\text { The } \\
\text { Accumulation } \\
\text { Mucus }\end{array}$ & \multicolumn{3}{c}{$\begin{array}{c}\text { Occurrence of Acute Respiratory } \\
\text { Distress Syndrome }\end{array}$} & & Total & p-value \\
& \cline { 2 - 6 } & $\begin{array}{c}\text { Respiratory } \\
\text { Distress }\end{array}$ & $\begin{array}{c}\text { Absent Respiratory } \\
\text { Distress }\end{array}$ & & \\
\cline { 2 - 7 } & $\mathbf{n}$ & $\%$ & $\mathbf{n}$ & $\%$ & $\mathbf{N}$ & $\%$ & \\
\hline Occurrence & 8 & 80,0 & 2 & 20,0 & 10 & 100,0 & \\
Unoccurrence & 3 & 33,3 & 6 & 66,7 & 9 & 100,0 & 0,040 \\
\hline
\end{tabular}

Table 5 shows that of the 10 patients who experienced mucus buildup, there were 8 major respiratory distresses $(80.0 \%)$. Of the 9 patients who without experience mucus buildup, most were not respiratory distress, 6 patients (66.7\%). Test results with coefficient coefficient obtained $p$ value $=0.040$. there is a statistically significant effect between the buildup of mucus on respiratory distress in traumatic brain injury at Prof. Dr. Margono Soekarjo hospital Purwokerto in 2017.

Munjiati', Walin ${ }^{2}$, Herry ${ }^{3}$ Diploma In Nursing, Polytechnic of Health Purwokerto-Semarang, Indonesia. Email: munjiatiifa@yahoo.co.id

Ferry ${ }^{4}$ Margono Soekarjo Hospital, Purwokerto, Indonesia 
Acute respiratory distress syndrome after traumatic brain injury in Purwokerto-Indonesia

Table 6. Consciousness Level and Acute Respiratory Distress Syndrome

\begin{tabular}{lccccccc}
\hline $\begin{array}{c}\text { Consciousness } \\
\text { Level }\end{array}$ & \multicolumn{3}{c}{$\begin{array}{c}\text { Occurrence of Acute Respiratory } \\
\text { Distress Syndrome }\end{array}$} & & Total & p-value \\
\cline { 2 - 6 } & $\begin{array}{c}\text { Respiratory } \\
\text { Distress }\end{array}$ & $\begin{array}{c}\text { Absent Respiratory } \\
\text { Distress }\end{array}$ & & & \\
\cline { 2 - 7 } & $\mathrm{n}$ & $\%$ & $\mathrm{n}$ & $\%$ & $\mathrm{~N}$ & $\%$ & \\
\hline Decrease & 8 & 88,9 & 1 & 11,1 & 9 & 100,0 & \\
Normal & 3 & 30,0 & 7 & 70,0 & 10 & 100,0 & 0,009 \\
\hline
\end{tabular}

Traumatic brain injury with respiratory distress as many as 9 patients $(47,36 \%)$ who experienced a decrease in consciousness, most of the respiratory distress occurred 8 patients (88.9\%). Statistical test results with the Contingency Coefficient obtained $p=$ 0.009 . There is a statistically significant effect between decreased conciousness of respiratory distress inTraumatic brain injury in Prof. Dr. Margono Soekarjo hospital Purwokerto in 2017.

\section{DISCUSSION}

Based on the research data, it is known that the age of respondents is mostly under 30 years, those aged between $16-22$ years 6 patient $(31.58 \%)$ and between $23-29$ years 7 patient (36.84\%) The results of the study are in accordance the results of previous studies, which stated that the percentage of causes of injury due to land transportation accidents was highest in the 15-24 years age group of $48.1 \%$ (Badan Statistik Nasional, 2013). most traumatic brain injury occur at the age of 25-44 years. This is because at that age, including the age active in various activities. One of them is the use of land transportation which is very susceptible to traumatic brain injury and other activities that have a high risk (Shi, Dong, Mao, Guan, Cao, Zhu, \& Wang, 2016). Based on research data it is known that 12 male respondents $(63.16 \%)$ are more than female respondents 7 (36.84) The results of the study are comparable to the data (Putrapratama, Wiraagni, \& Artanti, 2017). That the majority of accident victims were men $78.35 \%$ while women $21.65 \%$. According to which respondents were more male traumatic brain injury than women (Setyawan, Sukartini, Sriyono, \& Kusmiati, 2017).

This is because men have more activities that are at risk in traumatic brain injury, for example traffic drivers, jobs, and fights. According to the Traffic Safety Specialist at the World Bank, Jose Luis Irigoyen, developing countries such as Indonesia accounted for $90 \%$ of the number of deaths due to traffic accidents. Every day an average of 120 patient die from traffic accidents in Indonesia with $60 \%$ of deaths coming from two or three-wheeled motorists and $80 \%$ of the victims were men.

The results of the study found that there were 10 patient $(52.6 \%)$ more severe mucus in traumatic brain injury patients who did not experience 9 patient $(47.4 \%)$ mucus buildup from these data. Sputum buildup occurs is probably caused by several factors, including; infections of the respiratory tract, mucosal conditions, and rates of head / severe injury. Chest physiotherapy is one technique for removing excess sputum from the respiratory tract. The aim is to mobilize sputum and make breathing more effective. Besides returning the patient's physical abilities to level optimal (Pebriyanti, Sahidu, \& Sutrio, 2017).

Based on the results of the study note that patients with on traumatic brain injury who experienced a decrease in consciousness 9 patient $(47.4 \%)$ less than those who did not experience a decrease in consciousness (52.6\%). The condition of traumatic brain injury patients has a ten times the potential to experience neurological deficits and will worsen, which can be assessed using GCS, because GCS is an important scale for assessing the level of awareness, clinical status and prognosis of traumatic brain injury (Kramida, Ralchenko, \& Reader, 2015). The assessment saw an eye-opening response $(E=$ $4)$, verbal $(V=5)$, motor $(M=6)$, so it can be concluded as E4V5M6 with a total of 15 and minimum 3 (Iman, 2018).

Munjiati', Walin ${ }^{2}$, Herry ${ }^{3}$ Diploma In Nursing, Polytechnic of Health Purwokerto-Semarang, Indonesia.

Email: munjiatiifa@yahoo.co.id

Ferry ${ }^{4}$ Margono Soekarjo Hospital, Purwokerto, Indonesia 
Patients with traumatic brain injury Who experienced respiratory distress 11 patient (57.9\%) more than those who did not experience respiratory distress 8 patient (42.1\%). Traumatic brain injury is very important in managing ventilation and hypovolemia which play a role in causing secondary damage that can be prevented, because breathing distress can cause disability or death due to delay in resuscitation of hypoxia that mortality rates are higher in patients with oxygenation low brain tissue hypoxia of brain tissue below $10 \mathrm{~mm} \mathrm{Hg}$ associated with outcome poor after injury brain.

The results of the analysis using a statistical test with the Contingency Coefficient is known to have a statistically significant effect between the buildup of mucus on respiratory distress in traumatic brain injury Prof. Hospital Dr. Margono Soekarjo Purwokerto in 2017 ( $p=0.040)$. Mucus buildup is associated with respiratory distress in severe injury. Patients with traumatic brain injury will experience disability for move so as to experience immobilization, where the effects of immobilization will affect the psychological and physiological conditions of the individual. Physiological influences include metabolic changes and changes in the respiratory system such as decreased lung expansion, and muscle weakness. Respiratory failure experienced by patients one of which can be caused by airway obstruction due mucus to excessive so it needs to be done action

Mucus suctioning. Such actions must still pay attention to the patient's hemodynamics so that it is always maintained with stability (Saraswati \& Ulfa, 2019).

Based on the results of the analysis using tests statistical with Contingency Coefficient known to have a statistically significant effect between decreased awareness of respiratory distress on traumatic brain injury Prof Dr Margono Soekarjo Purwokerto Hospital in 2017 ( $p=0.009$ ). Oxygenation is a process of getting $\mathrm{O} 2$ and releasing CO2. This process involves system respiratory and system cardiovascular (Setyawan, 2017). If $\mathrm{PaO} 2$ is too low, it will cause hypoxia which can cause vasodilation of the blood vessels of the brain which will be followed by an increase in the rate of blood flow to the brain, and cause an increase in intracranial pressure (Hendrizal; Takatelide, Kumaat, \& Malara, 2017). The degree of awareness can be assessed qualitatively and quantitatively.assessment of degree of Qualitative Awareness can use the Glasgow Coma Scale (GCS).

Patients with loss of consciousness have a high risk for the occurrence of disorders of the airway, because loss of consciousness affects the respiratory distress. If $\mathrm{PaO} 2$ is too low, this will cause hypoxia, which can lead to vasodilation of the brain blood vessels which will be followed by an increase in the rate of flow blood to the brain increasing so that the condition will result in an increase in intracranial (Hendrizal \& Chandra; Takatelide, Kumaat, \& Malara, 2017). The results of a study conducted by Ratnasari 2015 low brain tissue oxygenation led to a higher mortality rate. The mortality rate is more than $50 \%$ in patients with brain tissue oxygenation of less than $10 \mathrm{mmHG}$ for 30 minutes.

\section{CONCLUSION}

Most Patients traumatic brain injury experience respiratory distress and mucus build up. There is a statistically significant effect between build up mucus between respiratory distress and traumatic brain injury .

\section{RECOMMENDATION}

Researchers hope this research can be additional information and also the researcher hopes that the researcher next will conduct quantitative and qualitative awareness research, and increase the number of more samples and conduct normality tests.

\section{REFERENCES}

Aveyard, R., Cooper, P., Fletcher, P. D., \& Rutherford, C. E. (1993). Foam breakdown by hydrophobic particles and nonpolar oil. Langmuir, 9(2), 604-613.

Badan Statistik Nasional. (2013). Indikator kesejahteraan rakyat. BPS. Jakarta.

Ban, S. P., Son, Y. J., Yang, H. J., Chung, Y. S., Lee, S. H., \& Han, D. H. (2010). Analysis of complications following decompressive craniectomy

Munjiati', Walin ${ }^{2}$, Herry ${ }^{3}$ Diploma In Nursing, Polytechnic of Health Purwokerto-Semarang, Indonesia.

Email: munjiatiifa@yahoo.co.id

Ferry ${ }^{4}$ Margono Soekarjo Hospital, Purwokerto, Indonesia 
for traumatic brain injury. Journal of Korean Neurosurgical Society, 48(3), 244.

Garey, E., Wuysang, H., \& Putra, D. (2015, June). Religious problem-solving style and life satisfaction in adolescents. meeting of American Counseling Association-Asia Pacific counseling conference.

Gherardi, S. (2019). How to conduct a practice-based study: Problems and methods. Edward Elgar Publishing.

Gustia, M., \& Manurung, M. (2018). Hubungan ketepatan penilaian triase dengan tingkat keberhasialan penanganan pasien cidera kepala di igd rsu hkbp balige kabupaten toba samosir. Jumantik (Jurnal IImiah Penelitian Kesehatan), 3(2), 98-114.

Hendrizal, H., \& Chandra, C. (2017, December). Preliminary Research Description In Developing Tematics Learning Materials by Using Character Building and Discovery Learning to Establish

Huda, S. A. (2018). Hubungan Dampak Katarak dengan Konsep Diri: Harga Diri Rendah pada Lansia di Desa Sukamanah Kecamatan Sukatani Kabupaten Bekasi Tahun 2015. Jurnal ilmiah keperawatan, 4(1).

Hutagalung, D. N. (2019). Proses keperawatan dalam melakukan dokumentasi keperawatan.

Iman, S. A. (2018). Hubungan skor glasgow coma scale (gcs) dengan kadar glukosa pada pasien cedera kepala di igd rsud dr. H. Abdul moeloek periode januari sampai maret 2017.

Kramida, A., Ralchenko, Y., \& Reader, J. (2015). NIST atomic spectra database (ver. 5.3).

Menk, A. V., Scharping, N. E., Moreci, R. S., Zeng, X., Guy, C., Salvatore, S., \& Delgoffe, G. M. (2018). Early TCR signaling induces rapid aerobic glycolysis enabling distinct acute $T$ cell effector functions. Cell reports, 22(6), 1509-1521.

Pebriyanti, D., Sahidu, H., \& Sutrio, S. (2017). Efektifitas Model Pembelajaran Perubahan Konseptual Untuk Mengatasi Miskonsepsi Fisika pada Siswa Kelas X Sman 1 Praya Barat Tahun Pelajaran 2012/2013. Jurnal Pendidikan Fisika dan Teknologi, 1(2), 92-96.

Putra, R. P., \& Rizalni, R. (2017). Analisis perbandingan kuat tekan paving block berbahan normal dengan paving block berbahan tambahan (Doctoral dissertation, Fakultas Teknik UNISSULA).

Putrapratama, P., Wiraagni, I. A., \& Artanti, M. S. T. (2017). Study of Traffic Accident Cases Based on Visum et Repertum in RSUP Dr. Soeradji Tirtonegoro Klaten Hospital During 20142016. International Journal of Medical Toxicology and Forensic Medicine, 7(3 (Summer)), 171-176.

Setyawan, S., Sukartini, T., Sriyono, S., \& Kusmiati, K. (2017). Oksigenasi dengan Bag and Mask 10 LPM Memperbaiki Asidosis Respiratorik. Jurnal Ners, 2(2), 72-76.

Shi, J., Dong, B., Mao, Y., Guan, W., Cao, J., Zhu, R., \& Wang, S. (2016). Traumatic brain injury and hyperglycemia, a potentially modifiable risk factor. Oncotarget, 7(43), 71052.

Silvia, L. (2019). kemampuan siswa kelas x sma negeri 3 langsa menulis teks negosiasi. Jurnal Samudra Bahasa, 2(1), 1-8.

Takatelide, F. W., Kumaat, L. T., \& Malara, R. T. (2017). Pengaruh Terapi Oksigenasi Nasal Prong Terhadap Perubahan Saturasi Oksigen Pasien Cedera Kepala Di Instalasi Gawat Darurat Rsup Prof. Dr. RD Kandou Manado. Jurnal Keperawatan, 5(1).

Ulfa, N. (2017). Hubungan kerasionalan penggunaan antibiotik dengan lama rawat inap pada pasien anak penderita demam tifoid di instalasi rawat inap rumah sakit umum daerah kardinah kota tegal periode 2016 (Doctoral dissertation, Fakultas Kedokteran UNISSULA).

Zhu, X., Wang, D., \& Craig, V. S. (2019). The interaction of particles with surfactant thin films: Implications for dust suppression. Langmuir.

Munjiati', Walin ${ }^{2}$, Herry ${ }^{3}$ Diploma In Nursing, Polytechnic of Health Purwokerto-Semarang, Indonesia.

Email: munjiatiifa@yahoo.co.id

Ferry ${ }^{4}$ Margono Soekarjo Hospital, Purwokerto, Indonesia 